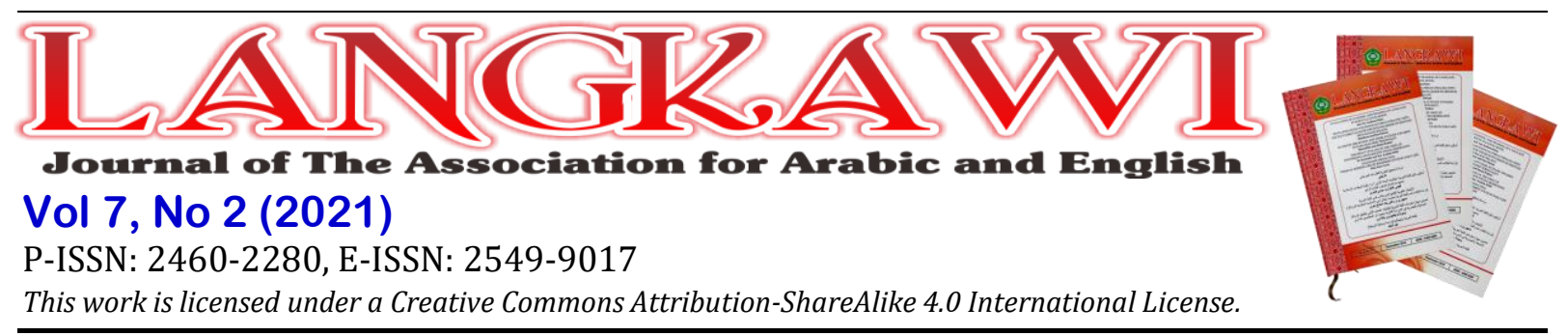

\title{
Femininity and Masculinity in Arabic Words: Gender Marking in Muslim Cosmology
}

\author{
Muassomah $^{1}$, Wildana Wargadinata ${ }^{2}$, Galuh Nur Rohmah ${ }^{3}$, Rohmani Nur Indah4, \\ Siti Masitoh ${ }^{5}$, Istiadah ${ }^{6}$, Irwan Abdullah ${ }^{7}$
}

${ }^{1}$ UIN Maulana Malik Ibrahim Malang, Indonesia. E-mail: muassomah@bsa.uin-malang.ac.id

${ }^{2}$ UIN Maulana Malik Ibrahim Malang, Indonesia. E-mail: wildana@bsa.uin-malang.ac.id

3UIN Maulana Malik Ibrahim Malang, Indonesia. E-mail: galuh98@bsi.uin-malang.ac.id

${ }^{4}$ UIN Maulana Malik Ibrahim Malang, Indonesia. E-mail: indah@bsi.uin-malang.ac.id

${ }^{5}$ UIN Maulana Malik Ibrahim Malang, Indonesia. E-mail: masitoh@bsi.uin-malang.ac.id

${ }^{6}$ UIN Maulana Malik Ibrahim Malang, Indonesia. E-mail: istihumaniora@bsi.uin-malang.ac.id

${ }^{7}$ Universitas Gadjah Mada, Yogyakarta, Indonesia. E-mail: irwan.fib@ugm.ac.id

*Corresponding author

\section{ARTICLE INFO}

\section{Keywords:}

Arabic words; Gender Marking;

Muslim cosmology

How to cite:

Muassomah, M., Wargadinata, W., Rohmah, G. N., Indah, R. N.,

Masitoh, S., Istiadah, I., Abdullah, I. (2021). Femininity and Masculinity in Arabic Words: Gender Marking in Muslim Cosmology. Langkawi: Journal of The Association for Arabic and English, 7(2), 182-196.

DOI:

http://dx.doi.org/10.31332/lkw.v7 $\underline{\mathrm{i} 2.3130}$

\section{History:}

Received: 2021-08-30

Accepted: 2021-12-17

Published: 2021-12-30

\begin{abstract}
The Modern Standard Arabic (MSA) language strongly indicates the sociolinguistic phenomenon as it reflects gender marking in language use. This study aims to explore how the Arabic letters attributed to specific gender identities, how the gender ideology of Arab culture create gender biases, and how the biases influence Arab social structure. It uses aspects of masculinity and femininity of Arabic letters that affect gender inequality and order of values on language, tradition and culture. Masculine letters are letters that have the property of being able to hold and entail other letters, while feminine letters that have the nature can be attached with other letters but cannot be attached. In this study, Arabic letters were mapped by observing their use in written and oral interaction in the contexts of Arab as first and second language. This research is a qualitative in nature. The data on ideology' influence on social structure were collected through interviews with three key informants representing their areas of expertise on language anthropology, sociolinguistic, and applied linguistic. The morphological analysis was carried out to identify the internal structure of the words. The sociolinguistic analysis explored the linguistic construction that to social construction. The finding showed that their internal structures, these letters were classified as masculine or feminine. From the sociolinguistic point of view, gender issues following social construction that has already formed gender relations. In other words, Arabic letters affect the order of values that tend to be gender-biased in the Arabic context.
\end{abstract}

\section{Introduction}

Gender inequality is a social construct and a linguistic construct (Eckert \& McCoonel-Ginet, 1999; Gormley, 2015). The social construction of society and culture triggers the occurrence of gender inequality. For example, gender inequality among the Arab people is partly constructed through the gendering (feminine and masculine elements) of the Arabic language. This inequality is created and comes from the patriarchal system and socio-economic factors (Azong \& Kelso, 2021) Each Arabic letter has its own gender, creating a distinct linguistic hierarchy. For example, the feminine letter waw (و) has limited capacity for creating words. It can only be 
connected to the letter that precedes it; waw cannot be connected to the letter that follows it.

Conversely, the masculine letter Jim (ج) can be connected both to the letter that precedes it and the letter that follows it. In other words, the Arabic language is structured by the gender biases inherent to its masculine and feminine elements. Experts have found that language is the most influential factor that structures gender relations. Male-female differences remain a relevant factor in the structure of society. Power and authority at all levels, from the household to the village and community level, is vested in men (Alhassan, 2014). Lexical choices and diction and grammatical and syntactical rules all expose the sexism inherent in the language (Menegatti \& Rubini, 2017; Weatherall, 2016).

Studies of the link between gender and language have found that language embodies particular inequalities and biases and may even be sexist and abusive (Menegatti \& Rubini, 2017; Park et al., 2018; Weatherall, 2016). When language benefits one sex over the other, it threatens the other sex and fosters gender discrimination. As in Arabic grammar which negates the feminine type if it joins the masculine. It means that no matter how many feminine subjects meet masculine subjects in one sentence, they will change verbs and pronouns to masculine. Linguistic studies have shown that sexism is found within words and proverbs (Weatherall, 2016) and in language's construction and maintenance of gendered binary oppositions (Cameron, 2014; Carli, 1990; Gormley, 2015; Huffaker \& Calvert, 2005; Stubbe, 2004). Theoretically, gender is motivated by the refutation of gender as a binary construct and the subversion of hegemonic categories, allowing for a multiplicity of femininities, masculinities, or androgynies (Coffey-Glover, 2015).

Gender, at the same time, is not a fixed social category, but a dynamic one constructed through language (Gormley, 2015). Language's construction of gender occurs, for example, through the use of sexist words and sentences and the contexts that inform and shape the language (Bolukbasi et al., 2016; Smyth, 2007; Wicha et al., 2004). "Letters" may similarly be gendered; Arabic letters, for example, have different qualities that determine their gender. This phenomenon, however, has not been seriously examined in the literature and thus is ripe for further research.

Responding to the paucity of studies examining language and gender, this article examines how distinguishing feminine and masculine characteristics are attributed to Arabic letters. This gendering strongly influences a letter's ability to connect with other letters. As such, three questions are relevant for this study: (1) how are Arabic letters attributed to specific gender identities, (2) how does the gender ideology of Arab culture and society create gender biases in the Arabic language, and (3) how do the gender biases in the Arabic language influence the Arab social structure. This article accordingly understands Arabic letters as expressing a gendered social system while simultaneously influencing the said system.

This study departs from the argument that the gendering of Arabic letters reflects a deeply rooted system of social categorization that remains sociologically practiced. The gendering of Arabic (language) words is derived from the patriarchal ideology that exists as a historical fact of Arab society and its lived sociological experiences. Language, together with the ideology that underpins it, is a force that while contested-exerts social and cultural power. Social practices occur within a 
linguistic framework; as such, gendered language -including gendered letters - is a historical product that has been internalized in everyday social discourses and practices.

\subsection{Language, Gender, and Identity}

All individuals have specific identities, including ethnics, religion, and national identities (Myhill, 2015; Zhang et al., 2019). one of fundamental identities is gender identity. the term firstly used in the medical literature in 1950s within the context of sexual development and gender dysphoria. Gender identity can be loosely defined as one's sense and perception of being male or female.

Stoller (year?) defines gender identity as one's sense of being male or female, reflective of one's genitalia at birth. As such, gender identity has often been conceptualized dichotomically, with male identity being opposed to female identity (Deogracias et al., 2007). However, such conceptualization cannot be applied to transgender, whose gender identity does not conform with their genitalia at birth. As such, gender identity has been more broadly defined as one's sense of being a particular sex. The binary conceptualization of gender has given way to a more dynamic one (Korpaisarn et al., 2019).

Gender identity is an essential element of one's personal identity. It helps regulate individuals' behaviors and social roles; particular behaviors, attributes, and personal characteristics are attributed to specific genders following cultural norms and values (Hamidi \& Nippoldt, 2019). Gender identity shapes how people view themselves and provides a foundation for their interactions with others (Steensma et al., 2013; Hamidi \& Nippoldt, 2019). Gender identities and expressions are multidimensional, involving a range of factors and the interactions between them.

Several other terms are also widely used in gender studies. Gender expressions are external manifestations of gender, including personal names, pronouns, clothing, haircuts, behaviors, physical characteristics, and vocal qualities. Sexual orientation, meanwhile, refers to the physical and emotional attraction to others. Some researchers have examined gender identity using a psychological approach, as seen in the study of sub-arctic Russian adolescents' gender identities conducted by Flotskaya et al. (2018). This article, meanwhile, applies a linguistic approach, understanding gender as structuring and being structured by language.

Gender inequality is commonly defined as the disparities experienced by men and women in education, health, decision-making, and wages (Shen, 2016; Looze et al., 2018). Lorber (2010) recognizes gender inequality as stemming from gendered social structures, wherein men and women are treated differently and provided with different opportunities. Many studies have examined gender inequality within the context of traditional gender norms, particularly the values they embody (Inglehart et al., 2003; Schwartz \& Rubel-Lifschitz, 2009). Branisa et al. (2012), meanwhile, have shown that gender inequality is an effect of formal and informal institutions' production and reproduction of distinct gender roles.

While recognizing the deleterious effect of gender inequality, it is necessary to ask whether it is a problem or a product of a problem. Gender inequality is not inherently related to sex; nonetheless, women are most commonly identified as the victims of gender inequality (Bhagavatheeswaran et al., 2016; de Looze et al., 2018; Singh et al., 2018; Thelwall et al., 2019). Chang et al. (2018) found that East Asian 
women are at greater risk of suicide due to their lower social status. Women have limited access to education and economic opportunities, a fact that limits their ability to grow and develop. Owing to their lower social status, women are more likely to experience violence and poverty.

Unequal access to education limits women's ability to access economic opportunities. In relation to this, Wegren et al. (2017) argue that gender inequality stems from the gender roles practiced in society. Through their association with domestic labor, the domestication of women negatively affects their professional development. The fact that men's entrepreneurial activities are most commonly undertaken further underscores the gender inequality that permeates the economic sector. Gender inequality is found in various places and religions, wherein men dominate the workforce and women experience significant structural challenges. Lekchiri et al. (2019) note that gender biases have a range of psychological effects exacerbated by the lack of organizational and structural coping mechanisms. They argue that women laborers can counter gender biases and obstacles with appropriate personal and organizational support.

Worldviews are androcentric, most commonly seeing men as representative of humankind and positioning men and masculinity as normative. Gender biases exist in language, as seen (for example) in the gendering of the German words for teachers (die Lehrerin/der Lehrer) or Indonesian words for reporters (wartawan/wartawati). In some languages, seemingly 'neutral' words have been used to erode the masculine/feminine dichotomy. However, these words tend to be of masculine origins; for example, the 'neutral' Norwegian word for teacher, lærer (historically lærer/lærerinne), and the Indonesian word for a sibling, saudara (historically saudara/saudari). Similarly, masculine biases are found in ostensibly neutral grammatical constructs (Lindqvist et al., 2018). MacArthur et al. (2019) have shown that many words, phrases, and discourses are used to subjugate, ignore, or stereotype a particular gender, with masculine labels being more commonly used than feminine ones.

Gender biases are also prominent in classrooms. Through language, female students are stereotyped as obeisant, tidy, and rule-abiding, while male students are identified as confident, active, and aggressive (Protivínský \& Münich, 2018). Science and scientific subjects are identified as masculine, while language and arts are identified as feminine (Mougharbel \& Bahous, 2010). Men and women are understood as experiencing and defining pain differently (Jaworska \& Ryan, 2018). Women tend to use more words, metaphors, and emotions in expressing their pain, which men tend to focus more on facts and descriptions. Where they use emotional expressions, women are stereotyped as crying, wailing, and expressing sadness, while men are understood as relying more on fact.

Language offers individuals an opportunity to recognize and express themselves as members of particular groups. Certain groups are stereotyped as sharing certain linguistic tendencies; for example, women in the Spanish workplace are more likely to use foreign languages than men. At the same time, however, wages are determined by sex and not by linguistic abilities (Coll et al., 2018). Where two workers speak the same language, their wages are informed by their sex (Ginsburgh \& Prieto-Rodriguez, 2013). Thus, while workers who speak foreign languages may be paid more than those who do not, men receive higher wages than women for the same work. 
Arabic, which boasts hundreds of millions of native speakers, is one of the most widely spoken languages on earth. It is also an integral part of Islam, a religion practiced by more than 1.5 billion people worldwide, where it is used for both practical and religious purposes. In written texts, the Arabic used reflects the age and sex of the author (Alsmearat et al., 2017). Although understandings of gender in society have transformed significantly, this shift has not been reflected in Arabic-language textbooks. The gender ratios, masculine and feminine language, honorifics, and grammatical structures of these texts clearly show inequality. Gender references in textbooks tend to favor men, while women are sub-optimally reflected (Al-Qatawneh \& Al Rawashdeh, 2019).

Arabic is a very gender-sensitive language. In Arabic-English translations, it is difficult to determine the appropriate use of predicates, pronouns, and other gendered terms; such difficulties are also experienced in all translations of gender-sensitive languages non-gender-sensitive ones. In English, for example, the subject-predicate relationship is not gendered. Conversely, in Arabic, the predicate must be conjugated by the gender of the subject (Hamdan \& Natour, 2014). Thus, it influences how English is translated to Arabic. The word who, for example, maybe translated in three ways, depending on the context. In the sentence "This is the man who found the answer", the word who must be translated using the singular male term الذي/alladhii, while in the sentence "This is the woman who found the answer" who must be translated using the singular female term التي / allatii; finally, in the sentence "This are the men who found the answer", the word who must be translated as الذين/alladhiina. Any mistakes will change the meaning of the entire sentence (Abu-Ayyash, 2017).

In a similar vein, Al-Ghadir and Azmi (2018) show that the use of Arabic on Twitter, including in retweets, is strongly gendered. Women are more likely use descriptive terms (i.e., use more words to convey their ideas), while men are less descriptive. Meanwhile, the gendered norms that regulate the interactions between men and women expect specific intonations, sentence structures, and word choices. Jordanian women, for example, maybe accused of violating social norms if they use particular pronunciations and diction. Women are expected to be more conservative and polite in their language use, in recognition of their status - as informed by structural and systemic gender inequality (Al-Harahsheh, 2014).

\section{Method}

Arabic was chosen as the material object of this article owing to its high level of gender sensitivity and attribution of masculine and feminine traits to specific letters. In Arabic, the vast majority of letters are masculine; only a small minority are feminine. However, from a morphological perspective, these letters are foundational and constitutional elements of words. Despite their inability to connect to the letters that follow them, such feminine letters are necessary for creating meaning.

This research is a qualitative one, intended to explore the linguistic practices of Arab society. More specifically, this study applies a morphological and sociolinguistic perspective in its analysis. Morphological analysis was used to examine the 'internal structure' of Arabic letters and their gender-biased connotations. Meanwhile, sociolinguistic analysis was applied to obtain an in-depth understanding of ideology's influence on this internal structure and to recognize its influence on the social structure of Arab society. 
Data were collected in several stages. At the first stage, Arabic letters were mapped by observing their use in written and oral contexts. Based on their internal structures, these letters were classified as masculine or feminine. Next, data on ideology's influence on social structure were collected through interviews with three key informants of Arabic; all of whom were teaching Arabic in Malang city. The key informants represented their areas of expertise in language anthropology, sociolinguistic, and applied linguistic. Semi-structured interviews, conducted in Arabic, were used to collect data regarding ideology's influence on letters and the influence of letters on the social structure. Before interviews were conducted, informants were provided a detailed explanation of the research project and its expected duration. For privacy purposes, data from informants were coded as follows: KI1 for the first key informant, KI2 for the second key informant, and KI3 for the third key informant.

Data were analyzed using three approaches. Each approach was chosen based on the aspect analyzed. First, masculine and feminine letters were analyzed using a morphological approach, which provided an understanding of their internal structures and facilitated comparison. Second, to understand the ideology underpinning the gender-biased structure of the Arabic language, the doctrines of Arab society were analyzed in depth. Finally, the influence of linguistic gender biases was analyzed by positioning the letters within the context of Arab society, including the oppositions of dominance-subordination, active-passive, and the subject-object that inform social transactions.

\section{Findings and Discussion}

\subsection{Arabic letters attributed to specific gender identities}

Arabic letters reflect a deep-rooted gender bias, one that imbues every letter with particular gender identity. The classification of Arabic letters by gender is summarized in table 1.

Table 1: Classification of Arab letters by gender

\begin{tabular}{|c|c|c|c|c|c|}
\hline No. & Masculine & No & Masculine & No. & Feminine \\
\hline 1 & $\varphi$ & 12 & ظ & 1 & 1 \\
\hline 2 & $ت$ & 13 & $\varepsilon$ & 2 & د \\
\hline 3 & ث & 14 & $\dot{\varepsilon}$ & 3 & $\dot{j}$ \\
\hline 4 & ج & 15 & ف & 4 & J \\
\hline 5 & $\tau$ & 16 & ق & 5 & j \\
\hline 6 & $\dot{\tau}$ & 17 & ك & 6 & و \\
\hline 7 & س & 18 & J & & \\
\hline 8 & ش & 19 & s & & \\
\hline 9 & ص & 20 & ن & & \\
\hline 10 & ض & 21 & هـ & & \\
\hline 11 & $b$ & 22 & ي & & \\
\hline
\end{tabular}


As seen in table 1, masculine Arabic letters can connect to the letters that precede them and the letters that follow them. For example, the letter "ب in the word ثبتcan link to the letter "ث", while the letter "ب" can link to the letter "ت". It reflects the particular dominance of the 22 masculine letters in Arabic. Meanwhile, feminine letters - of which there are only six - can not be linked to the letters that follow them. For example, the word خرجshows that the letter " precedes it ("خ"), but it cannot link to the letter that follows it ("ج"). It indicates that feminine letters are passive, positioned as objects, while masculine letters can be simultaneously active and passive (i.e., positioned simultaneously as subjects and objects).

Table 1 shows three main tendencies in Arabic letters. First, masculine letters are more numerous than feminine letters, which implies that these letters occupy different levels in a gendered hierarchy. Second, letters that are classified as feminine

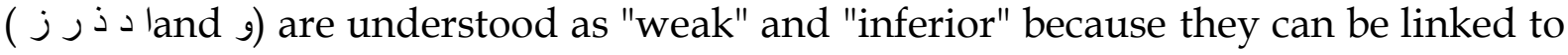
the masculine letters that precede them, but cannot link to the feminine or masculine letters that follow them. Third, feminine letters are integral in creating Arabic words, as despite being "inferior" they occupy strategic positions. The letter "و", for example, is an important part of the word يقول, as its absence would change the meaning/denotation of said word. As such, feminine letters cannot fairly be identified as passive and marginal.

\subsection{The ideology of Arab culture that creates gender biases in the Arabic language}

Feminine letters are fewer in Arabic (see table 1). They are integral to wordformation. Several of these feminine letters cannot simply be ignored, branded as passive and marginal. The androcentric worldview puts the position of men as representing all of humankind and normatively presenting men and masculinity as the most desirable and most correct. As stated by Bogetić, "the fundamental initial aspects of the concept of hegemonic masculinity have been retained and continue to exert a strong influence on the thinking about gender and social hierarchy" (Bogetić, 2013). Such a phenomenon is less prevalent in relatively egalitarian languages such as, for example, Indonesian, where words such as dia (a third person singular pronoun) can be used to refer to persons of all sexes and genders. While in Arabic language, the third person singular pronoun is huwa (هو).

The relation between the ideology of Arab culture and gender bias as reported by the three key informants of this study is demonstrated in table 2 .

In more egalitarian languages, gender identities only become evident through affixation. For example, the masculine-feminine dichotomy in the German-language words die Lehrerin/der Lehrer (teacher) and the Indonesian-language words mahasiswa/mahasiswi (university student). It differs significantly from Arabic, in which gender affects affixes and phrases and even sentence structures. As such, the gender identities integral to Arabic cannot easily be translated to other languages; conversely, when translating from such languages to Arabic, translators must know the sex of the subject and choose the appropriate verb (Hamdan \& Natour, 2014). This difficulty is not experienced when translating Arabic into an equally gender-sensitive language, such as Persian. This is relevant to the finding of this study, as presented in table 2. 
Table 2. Ideology and gender bias

\begin{tabular}{|c|c|c|}
\hline Key Informants & Ideology of Arab culture & Gender bias \\
\hline $\begin{array}{l}\text { 1. Language } \\
\text { anthropology }\end{array}$ & $\begin{array}{l}\text { In the Arab social } \\
\text { stratification, a man was } \\
\text { given the authority and } \\
\text { power to play a role in } \\
\text { activities related to law, } \\
\text { leading businesses, } \\
\text { governing the country, } \\
\text { and making financial } \\
\text { decisions. }\end{array}$ & $\begin{array}{l}\text { Masculine words are } \\
\text { more dominant than } \\
\text { feminine in many } \\
\text { aspects. For example, in } \\
\text { taking an oath as a } \\
\text { witness, masculine } \\
\text { pronouns are used. This } \\
\text { is because women cannot } \\
\text { be witnesses. }\end{array}$ \\
\hline 2. Sociolinguist & $\begin{array}{l}\text { Women were framed as } \\
\text { subordinate, as burdens } \\
\text { to their tribes, and } \\
\text { ultimately as eroding the } \\
\text { solidarity and power of } \\
\text { the tribe }\end{array}$ & $\begin{array}{l}\text { In translating male } \\
\text { pronouns, they must pay } \\
\text { attention to the order that } \\
\text { prioritizes the mention of } \\
\text { masculine over feminine. } \\
\text { For example in English } \\
\text { "ladies and gentlemen", } \\
\text { then in Arabic the } \\
\text { pronunciation becomes I } \\
\text { الإخوة (al ikhwa wal } \\
\text { akhwat) or gentlemen } \\
\text { and ladies. }\end{array}$ \\
\hline 3. Applied linguistics & $\begin{array}{l}\text { Men dominate public } \\
\text { spaces while women are } \\
\text { associated with domestic } \\
\text { spaces. Such a concept of } \\
\text { space also underpins the } \\
\text { symbolic structure of the } \\
\text { Arabic language, wherein } \\
\text { men are identified with } \\
\text { the public and women } \\
\text { with the private. }\end{array}$ & $\begin{array}{l}\text { Semiotic consequences } \\
\text { arise when referring to } \\
\text { symbols and illustrations } \\
\text { that appear in Arabic } \\
\text { learning books and } \\
\text { symbols used in other } \\
\text { public domains. }\end{array}$ \\
\hline
\end{tabular}

Arabic letters are strongly influenced by the patriarchal ideology of pre-Islamic Arabia, one rooted in a spatial dichotomy (Mernissi, 1994, in Sadiqi, 2006) wherein men dominate public spaces while women are associated with domestic spaces. The finding in Table 2 mentions that such a concept of space also underpins the symbolic structure of the Arabic language, wherein men are identified with the public and women with the private. Public rituals and cultural practices, including communal prayers, are linked to women, while private ones such as childbirth are associated with women. It reflects the finding by Branisa et al. (2012) that gender inequality develops through both formal and informal channels, and it is through these channels that gender inequality deleteriously affects society.

In the Arabic language, gender identities are created and negotiated through power. The personal is culturally associated with the disenfranchised (women and children) and positioned as subordinate to the public (i.e., subordinate to male- 
dominated spheres). The binary division of humanity into females and males results from iconization (Coady, 2018). As shown in Table 2, within the Arab social structure, men are given the authority and power to make legal judgments, lead businesses, govern countries, and make financial decisions (domestic and public). This finding is in line with Sadiqi (2006) explains that Arab Muslim men are socially recognized as having the authority to control public and private spaces; this social recognition is reaffirmed through sharia family laws.

Similarly, the gender identities of Arabic letters are reaffirmed through religious spaces and structures, wherein women have less agency than men. In the Arab world, women rarely pray loudly or lead religious rituals. The patriarchy frequently exploits this to argue that women should not have public power-even as terms such as imama (female leader), faqiha (female religious consultant), muftiya (female religious legislator), musaliya (female prayer leader), muqri'ah (female Quranic reader), and mujewwida (woman who memorized the Quran) indicate that women are involved in religious affairs. As a result, women have been excluded from the political arena and disqualified as competent public speakers, and as such have spent decades struggling for public visibility. It has created a paradox in which women are simultaneously perceived as lacking a role as social leaders while being entrusted with the conservation and transmission of languages, traditions, and cultural values (Sadiqi, 2006).

A society's ideology and structure strongly influence various aspects of social life, including its symbols and its language. A society's language and the ideology it embodies are a manifestation of its culture, which influences how it sees the world, how its members behave, and how its members communicate with each other. For example, Wahabism, which claims to trace its roots to seventh-century Islam and the leadership of the Prophet Muhammad (and subsequently the Rashidun Caliphate), has long been the formal ideology of the Arabian Peninsula. Within this ideology, religion and politics are seen as integrated into a singular whole; this belief thus underpins all of Arab society, doctrine, and culture (Determann, 2013, Abidin, 2015).

In the pre-Islamic era, the Arab people lived in isolated tribes. Tensions were significant, and conflicts often broke out as tribes sought to control oases and other necessary resources. This warfare shaped the discrimination experienced by women, as tribes prioritized men and male children-who were seen as necessary for warfare-over women and female children. The finding in Table 2 stated that women were framed as subordinate, as burdens to their tribes, and ultimately as eroding the solidarity and power of the tribe. The practice of $w a^{\prime} d u l$ bannat emerged during this period; the birth of a female child was seen as an ill omen, and such children were frequently buried alive in the form of female infanticide. Only fertile women, those who produced many sons, were given a privileged position in the tribe (Wargadinata \& Fitriani, 2008).

Language reflects the culture of its users; the Arabic language, thus, reflects Arab culture. As a product of Arab culture, the Arabic language reflects a mainly Arab mindset. It is a system of symbols that conveys particular meanings (Al-Quzwaini, 1993: 149). These symbols are rooted in the everyday lives of the Arab people, and as such, Arabic is closely associated with and strongly influenced by their everyday lives. Their language is influenced by their mindset, as manifested in their social behavior 
(Trigg, 1985: 188). In other words, Arab society and social structures are reflected in the Arabic language and its letters.

Arab letters reflect the Arab social structure, including its hierarchal subordination of women. Consequently, letters identified as feminine - such as " are also understood as subordinate/marginal. At the same time, however, these letters (as part of the language) also structure Arab social life. The letter "و", as found in the word يقول, has the ability to structure society through its conveyance of particular social desires and activities. Stratification thus occurs under the "direction" of language.

\subsection{The influence of gender biases in the Arabic language on the Arab social structure}

There is an apparent numerical disparity in the number of masculine and feminine letters in Arabic, with the predominant masculine letters (22, 79\%). The dominance of men and masculinity is also reflected in Arab social structure. For example, KI1 stated that men are most active in the public sphere in Sudan, while women are predominantly found in the domestic sphere. Women have comparatively little mobility; unlike men, who may travel freely, women may not leave their homes unless they travel with unmarriageable kin (mahram) and wear a niqab. KI2 clarified that women are only allowed to teach at the primary school level, which integrates male and female students; all teachers must be men at the secondary and tertiary levels. Similarly, KI3 indicated that women may not receive male guests in Libya and Egypt. The dominance of men in Sudan, Libya, and Egypt suggests that the dominance of men influences all elements of Arab society, including the letters used in Arabic.

A study of gender representation in Arabic-language textbooks in the United Arab Emirates makes a similar point; men are dominant, while women are positioned as secondary citizens. Al-Qatawneh and Al Rawashdeh (2019) recommend a more equitable representation of gender in textbooks. Similar gender biases are found in the textbooks used to teach Islam to Muslim schoolchildren in Indonesia. Examining the religious textbooks used at the elementary-school level (Madrasah Ibtidaiyah), Suwardi et al. (2018) find that these textbooks' illustrations are gender-biased. In the Middle East, women often feel that their ability to ask questions, express their opinions, and become involved in classroom discussions is stifled. Williams (2019) identifies this as a major obstacle for English-language education in the region, which necessitates active classroom participation.

The gender biases that permeate Arabic letters contribute to the structuring of Arab society. Specific letters and sounds can convey particular gender identities, even outside of their ability to link to other letters. Take, for example, the Arabic-language names "حميد، حميدة" and "حمود، محمودة" "طيب، طيبة " Undike in Indonesian, where vocal alternation is used to distinguish between men and women (viz. Soekarno vs. Soekarni), these names are gendered through the round $t a("$ " $")$.

\section{Conclusion}

This article has explored the dialectic relationship between linguistic reality and social reality, with the language being directly linked to social constructs. The Arabic language reflects social reality, which reflects the practice of patriarchal culture in various aspects of life, wherein social identities are not only determined by sex but also by masculine or feminine qualities. It can be seen, for example, in Arabic letters 
differential capacities to link with other letters. The finding of this study shows that the masculine letters are far more dominant than feminine ones, as they can link to the letters that precede them and the letters that follow them. On the other hand, feminine letters are more limited in their linking capacity. They can only be linked with the letters that precede them; they are frequently identified as passive and subordinate. Such a structural condition is also found in Arab society. Language reflects this social reality and structures it; similarly, letters not only communicate ideas but also structure of human behaviour and social interactions. In this case, the masculine has wider access than the feminine.

The perspective used in this study has contributed a new insight for understanding language. The application of gender theory for linguistic research has shown a clear link between gender and language; it is also apparent how Arabic letters reflect gender relations and structures. More specifically, this study has confirmed that-even at the letter level-language conveys particular gender identities, inequalities, and biases, which is illustrative of real-world gender relations. This study's application of morphological and sociolinguistic analysis has enabled it to explore Arabic letters in detail holistically. It is done through the interconnection between the structure in an Arabic word and the social context. At the morphological level, Arabic letters may be classified as masculine and feminine. Meanwhile, at the sociolinguistic level, Arabic letters reflect a specific gender ideology that has deep historical roots and present-day relevance. The gender identity of the Arabic letter as the builder of the Arab social order reflects the ideology of gender bias which is one of the contemporary issues of sociolinguistics. Such sociolinguistic analysis has also provided an essential tool for revealing how language influences the social structure and the social structure influences language.

This study's main limitation is its reliance on textual interpretation rather than empirical analysis. Therefore, an empirical study should be conducted amongst users to better understand how language is structured by (and structures) reality. Such an empirical study should examine language use in Arab society to determine the extent to which its patriarchal ideology, as embodied within the Arabic language, structures the social lives of the Arab people. At the same time, this study should examine how the dominant gender ideology structures language. Further research should also compare the Arabic used by native speakers from different ideological backgrounds, using this approach to provide a new perspective on how language is structured by and structures society.

\section{References}

Abidin, Z. (2015). Wahabisme, Transnasionalisme dan gerakan-gerakan radikal Islam di Indonesia [Wahhabism, Transnationalism and Islamic radical movements in Indonesia]. Tasamuh, 12(2), 130-148.

Abu-Ayyash, E.A.S. (2017). Errors and non-errors in English-Arabic machine translation of gender-bound constructs in technical texts. Procedia Computer Science, 117, 73-80. doi: 10.1016/j.procs.2017.10.095.

Al-Ghadir, A.I., \& Azmi, A.M. (2019). A study of Arabic social media users - posting behavior and author's gender prediction. Cognitive Computation, 11(1), 71-86. doi: 10.1007/s12559-018-9592-7. 
Al-Harahsheh, A.M.A. (2014). Language and gender differences in Jordanian-spoken Arabic: a sociolinguistics perspective. Theory and Practice in Language Studies, 4(5), 872. doi:10.4304/tpls.4.5.872-882.

Al-Qatawneh, S., \& Al Rawashdeh, A. (2019). Gender representation in the Arabic language textbook for the ninth grade approved by the Ministry of Education for use in schools in the United Arab Emirates (UAE). Studies in Educational Evaluation, 60, 90-98. doi: 10.1016/j.stueduc.2018.12.001.

Al-Qatawneh, S., \& Al Rawashdeh, A. (2019). Gender representation in the Arabic language textbook for the ninth grade approved by the Ministry of Education for use in schools in the United Arab Emirates (UAE). Studies in Educational Evaluation, 60, 90-98.

Al-Quzwaini. (1993). Al-Idloh fi Ulum il-Balaghah, Beirut: Dar al-Jail.

Alhassan, Salifu Nantogma. (2014). Sexism and gender stereotyping in the Dagbanli language. Gender and Language, 8(3) 393-415

Alsmearat, K., Al-Ayyoub, M., Al-Shalabi, R., \& Kanaan, G. (2017). Author gender identification from Arabic text. Journal of Information Security and Applications, 35, 85-95. doi: $10.1016 /$ j.jisa.2017.06.003

Azong, M. N., \& Kelso, C. J. (2021). Gender, ethnicity and vulnerability to climate change: The case of matrilineal and patrilineal societies in Bamenda Highlands Region, Cameroon. Global Environmental Change, 67, 102241. doi: 10.1016/j.gloenvcha.

Bhagavatheeswaran, L., Nair, S., Stone, H., Isac, S., Hiremath, T., Raghavendra, T., et al. (2016). The barriers and enablers to education among scheduled caste and scheduled tribe adolescent girls in northern Karnataka, South India: A qualitative study. International Journal of Educational Development, 49, 262-270.

Bogetić, K. (2013). Normal straight gays: Lexical collocations and ideologies of masculinity in personal ads of Serbian gay teenagers, 7(3), 333-367

Bolukbasi, T., Chang, K.W., Zou, J.Y., Saligrama, V., \& Kalai, A.T. (2016). Man is to computer programmer as woman is to homemaker? Debiasing word embeddings. In Advances in Neural Information Processing Systems (pp. 4349-4357).

Branisa, B., Klasen, S., \& Ziegler, M. (2013). Gender inequality in social institutions and gendered development outcomes. World Development, 45, 252-268. doi: 10.1016/j.worlddev.2012.12.003

Cameron, D. (2014). 14 gender and language ideologies. In The Handbook of Language, Gender, and Sexuality, 281.

Carli, L.L. (1990). Gender, language, and influence. Journal of Personality and Social Psychology, 59(5), 941.

Chang, Q., Yip, P.S., \& Chen, Y.Y. (2019). Gender inequality and suicide gender ratios in the world. Journal of Affective Disorders, 243, 297-304.

Coady, Ann. (2018). The Origin of Sexism in Language. Gender and Language 12(3), 271293.

Coffey-Glover, L. (2015). Ideologies of masculinity in women's magazines: a critical stylistic approach. Gender and Language, 9(3), 337-364.

De Looze, M., Elgar, F.J., Currie, C., Kolip, P., \& Stevens, G. W. (2019). Gender inequality and sex differences in physical fighting, physical activity, and injury 
among adolescents across 36 countries. Journal of Adolescent Health, 64(5), 657-663. doi: 10.1016/j.jadohealth.2018.11.007

Deogracias, J.J., Johnson, L.L., Meyer-Bahlburg, H.F., Kessler, S.J., Schober, J.M., \& Zucker, K.J. (2007). The gender identity/gender dysphoria questionnaire for adolescents and adults. Journal of Sex Research, 44(4), 370-379.

Determann, J.M. (2013). Historiography in Saudi Arabia: globalization and the state in the Middle East, 42. IB Tauris.

Eckert, P., \& McConnell-Ginet, S. (1999). New generalizations and explanations in language and gender research. Language in Society, 28(2), 185-201.

Flotskaya, N., Bulanova, S., Ponomareva, M., Flotskiy, N., \& Konopleva, T. (2018). Gender identity development among teenagers living in the subarctic region of Russia. Behavioral Sciences, 8(10), 90. doi: 10.3390/bs8100090.

Garcia Coll, C., Garcia Miranda, A., Buzzetta Torres, I., \& Nogueras Bermúdez, J. (2018). On becoming cultural beings: a focus on race, gender, and language. Research in Human Development, 15(3-4), 332-344. doi: 10.1080/15427609.2018.1491217.

Ginsburgh, V., \& Prieto-Rodriguez, J. (2013). Is there a gender bias in the use of foreign languages in Europe? Kyklos, 66(4), 552-566. doi: 10.1111/kykl.12035.

Gormley, S. (2015). Language and gender. In International Encyclopaedia of Social $\mathcal{E}$ Behavioral Sciences (second edition). doi: 10.1016/B978-0-08-097086-8.53055-4.

Hamdan, J.M., \& Natour, Y.S. (2014). Gender of cited authors: A problem for the English-Arabic translation of scholarly research. Babel, 60(3), 265-280. doi: 10.1075/babel.60.3.01ham.

Hamidi, O., \& Nippoldt, T. B. (2019). Biology of gender identity and gender incongruence. In Transgender Medicine (pp. 39-50). Humana Press, Cham.

Huffaker, D.A., \& Calvert, S.L. (2005). Gender, identity, and language use in teenage blogs. Journal of Computer-Mediated Communication, 10(2), JCMC10211.

Inglehart, R., Norris, P., \& Ronald, I. (2003). Rising tide: gender equality and cultural change around the world. Cambridge University Press.

Jaworska, S., \& Ryan, K. (2018). Gender and the language of pain in chronic and terminal illness: A corpus-based discourse analysis of patients' narratives. Social Science E Medicine, 215, 107-114. doi: 10.1016/j.socscimed.2018.09.002.

Korpaisarn, S., \& Safer, J.D. (2019). Etiology of gender identity. Endocrinology and Metabolism Clinics, 48(2), 323-329. doi: 10.1016/j.ecl.2019.01.002.

Lekchiri, S., Crowder, C., Schnerre, A., \& Eversole, B.A. (2019). Perceived workplace gender-bias and psychological impact: The case of women in a Moroccan higher education institution. European Journal of Training and Development, 43(3/4), 339353.

Lindqvist, A., Renström, E. A., \& Sendén, M. G. (2019). Reducing a male bias in language? Establishing the efficiency of three different gender-fair language strategies. Sex Roles, 81(1-2), 109-117. doi: 10.1007/s11199-018-0974-9.

Lorber, J. 2010. Gender inequality. Oxford University Press.

MacArthur, H.J., Cundiff, J.L., \& Mehl, M.R. (2019). Estimating the prevalence of gender-biased language in undergraduates' everyday speech. Sex Roles, 1-13. doi: 10.1007/s11199-019-01033-z. 
Menegatti, M., \& Rubini, M. (2017). Gender bias and sexism in language. In Oxford Research Encyclopedia of Communication. Oxford University Press.

Mougharbel, G.M., \& Bahous, R. (2010). Gender bias in Lebanese language classes. The Educational Forum, 74(3), 198-212. doi: 10.1080/00131725.2010.483901.

Myhill, J. (2015). Religion: nationalism and identity. International Encyclopedia of the Social \& Behavioral Sciences, 338-343. doi: 10.1016/b978-0-08-097086-8.84037-4.

Park, J.H., Shin, J., \& Fung, P. (2018). Reducing gender bias in abusive language detection. arXiv:1808.07231.

Protivínský, T., \& Münich, D. (2018). Gender bias in teachers' grading: what is in the grade. Studies in Educational Evaluation, 59, 141-149. doi: 10.1016/j.stueduc.2018.07.006.

Sadiqi, F. (2006). Gender in Arabic. The Brill Encyclopedia of Linguistics, 2, 642-650.

Schwartz, S.H., \& Rubel-Lifschitz, T. (2009). Cross-national variation in the size of sex differences in values: effects of gender equality. Journal of Personality and Social Psychology, 97(1), 171.

Shen, K., et al. 2016. Patterns of inequalities in public transfers by gender in China. The Journal of the Economics of Ageing. doi: 10.1016/j.jeoa.2016.04.005

Singh, R., \& Mukherjee, P. (2018). 'Whatever she may study, she can't escape from washing dishes': gender inequity in secondary education-evidence from a longitudinal study in India. Compare: A Journal of Comparative and International Education, 48(2), 262-280.

Smyth, E. (2007). Gender and education. In International Studies in Educational Inequality, Theory and Policy (pp. 135-153). Springer, Dordrecht.

Steensma, T.D., Kreukels, B.P., de Vries, A.L., \& Cohen-Kettenis, P.T. (2013). Gender identity development in adolescence. Hormones and Behavior, 64(2), 288-297.

Stubbe, M. (2004). Gender, language and discourse. Women in Management Review, 19(2), 123-125.

Suwardi, S., Anitah, S., Akhyar, M., \& Asrowi, A. (2018). Gender bias in Islamic textbooks for Muslim children in Indonesia. Attarbiyah: Journal of Islamic Culture and Education, 2(2), 214-235.

Thelwall, M., Bailey, C., Makita, M., Sud, P., \& Madalli, D.P. (2019). Gender and research publishing in India: Uniformly high inequality? Journal of Infometrics, 13(1), 118-131. doi: 10.1016/j.joi.2018.12.003

Trigg, R. (1985). Understanding social science: a philosophical introduction to the social sciences. Oxford: Blackwell.

Wargadinata, W. \& Fitriani, L. (2008). Sastra Arab lintas budaya [Cross-cultural Arabic literature]. Malang: UIN Maliki Press.

Weatherall, A. (2016). Sexism in language. In The Wiley Blackwell Encyclopedia of Gender and Sexuality Studies, 1-2.

Wegren, S.K., Nikulin, A., Trotsuk, I., \& Golovina, S. (2017). Gender inequality in Russia's rural informal economy. Communist and Post-Communist Studies, 50(2), 87-98. doi: 10.1016/j.postcomstud.2017.05.007.

Wicha, N.Y.Y., Moreno, E.M., and Kutas, M. (2004). Anticipating words and their gender: an event-related brain potential study of semantic integration, gender expectancy, and gender agreement in Spanish sentence reading. Journal of Cognitive Neuroscience, 16, 1272-1288. doi: 10.1162/0898929041920487. 
Williams, L. (2019). Language, gender, and voice: empowering Arabic women in the ESL classroom. Unpublished doctoral dissertation, California State University, Northridge.

Zhang, C.X., Fong, L.H.N., Li, S., \& Ly, T.P. (2019). National identity and cultural festivals in postcolonial destinations. Tourism Management, 73, 94-104. doi: 10.1016/j.tourman.2019.01.013. 